Impact Factor: 4.845(SJIF) Research Journal Of English (RJOE) Vol-5, Issue-2, 2020

www.rjoe.org.in An International Peer-Reviewed English Journal

ISSN: 2456-2696

Indexed in: International Citation Indexing (ICI), International Scientific Indexing

(ISI), Directory of Research Journal Indexing (DRJI) Google Scholar \& Cosmos.

\title{
THE TEACHER WHO TALKS A LOT IS TEACHING A LOT: REALLY?
}

\section{Dr Ankita Khanna}

Associate Professor, School of Liberal Arts \& Management Studies

P P Savani University, Surat, Gujarat

\begin{abstract}
The evolution of Communicative Language Teaching (CLT) conveyed with it a methodology, which emphasised communication in the classroom, pair and group activities and student involvement in the learning process. The shift was from 'learning the language' to 'using the language'. Distinguishing it from the previous methods, this method advocated 'student-led class' as compared to 'student-centered class'. The learning happens through meaningful and focused student interaction in the target language, leaving no scope for teacher to talk a lot. Many theories based on CLT insist that teacher talking time (TTT) is counterproductive and that teachers should reduce TTT and encourage student talking time (STT). This paper dwells upon the idea of reducing TTT and providing more opportunities to learners by increasing STT. It proposes to understand the reasons for the increased TTT and provides rationale and solutions to overcome it. The suggestions in this paper are drafted to be of use to the educators of English as a Second Language at various levels of teaching. It is hoped that the recommendations in this paper will provide a fresh insight to teacher's role in the foreign language learning classrooms.
\end{abstract}

\section{Introduction}

Communicative Language Teaching is a natural follow-on from the reaction during the 70s against previous methods which over-focused on teaching grammatical structures and template sentences, and which gave little or no importance to how language is actually used practically. It emphasizes on the student-led classrooms and focuses on reducing TTT in the language classrooms. Most of the times, it is believed by the teachers that they are the fountain of knowledge and their duty is to disseminate the knowledge to the world; for which they resort to delivering lectures. This maybe a good approach for the disciplines that are more 'content' oriented, however, for the language teaching where the objective is not accumulation of any principles, rules or theories, it may not be appropriate. Broadly, disciplines dealt in the Schools and Universities can be categorized into 'knowledge based disciplines' and 'skill based discipline'. To elaborate upon this I would like to give an example of a philosophy class or a literature class. Such classes demand intense discussions and sometimes even teacher-led approach. Whereas in classes like soft skills, communication skills or language learning, the approach has to be different. The talk time 
Impact Factor: 4.845(SJIF) Research Journal Of English (RJOE) Vol-5, Issue-2, 2020

www.rjoe.org.in An International Peer-Reviewed English Journal

ISSN: 2456-2696

Indexed in: International Citation Indexing (ICI), International Scientific Indexing (ISI), Directory of Research Journal Indexing (DRJI) Google Scholar \& Cosmos.

allocated to students needs to be much higher than that of teacher because skill cannot be acquired by merely listening to the lectures. It is like learning to drive a car or swim by listening to the lectures. One needs to dive in the pool to learn to swim and the one to dive should be the learner not the swimming coach. The coach however needs to facilitate the process of swimming and monitor the progress of the aspiring swimmer.

Teaching does not equate with learning. Just because the first one is taking place, the latter one is not assured. Learning demands energy, involvement and participation. It is quite possible that despite many efforts from the teacher, learning is not taking place. It is a widespread notion that merely attending the class or listening attentively to teacher will ensure learning. To some it may also pose the question about the role of the teacher. Whether it is to participate, monitor or vanish?

The role of a teacher in the classroom varies from situation to situation. And also, depends on the focus of the lesson; whether it is fluency or accuracy. In some cases, especially with more challenging lessons, active participation, fully or partially, is required. In some situations, monitoring is the best tool, where students are on their own, discovering and learning; and teacher makes sure that they are on right track. Teacher may, occasionally, intervene and guide students. Vanishing from the classroom does not mean physical absence of teacher. Teacher, in this case, allows learners to be themselves, provide scope of making errors and correcting them later on, in the self-discovery mode.

\section{Literature Review}

Dagmar Rosenbergová in her paper STT vs TTT writes, "Teacher talking time (TTT) is the time that teachers spend talking in class, while student-talking time (STT) is the time the students spend talking in the class. STT vs. TTT is extremely problematic and complex area of English teaching."

Jeremy Harmer in the book 'How to teach English' states that "Overuse of TTT is inappropriate because the more a teacher talks, the less chance there is for the students to practise their own speaking - and it is the students who need the practice, not the teacher. If a teacher talks and talks, ............maximises STT and minimises TTT.” (p. 38)

Jim Scrivener in the book 'Learning Teaching' states "We never know how much learning is taking place. It is tempting to imagine that if teaching is going on, then the learning must be happening; but in fact, 'teaching' and 'learning' need to be clearly distinguished."

\section{Findings and Discussion}


Impact Factor: 4.845(SJIF) Research Journal Of English (RJOE) Vol-5, Issue-2, 2020

www.rjoe.org.in An International Peer-Reviewed English Journal

ISSN: 2456-2696

Indexed in: International Citation Indexing (ICI), International Scientific Indexing (ISI), Directory of Research Journal Indexing (DRJI) Google Scholar \& Cosmos.

According to many studies conducted, the amount of TTT should reduce for number of reasons. The first on the list is that it consumes time that is ideally meant for students to use. In a recent speech at a Visible Learning Conference in Horsens, Denmark, John Hattie said that in his research, teachers ask around "250 questions per day per week." On the other hand, he stated that students ask questions at a range of "2 per class per week." According to that meta-analysis of numerous studies, teachers ask many more questions than their students ever get a chance to ask. That is a lot of monologue with very little dialogue. They need to shift their mind set from being the fountain of all learning to being ok with the idea that students should not only ask numerous questions for understanding, but also contribute to the discussion without asking questions.

Also, with one person doing all the talking and rest all receiving it as passive listeners, the sessions get monotonous and students lose interest. It is important to have interactive classroom and enhanced student participation not only for the purpose of learning but also to retain students' interest. One of the major flaws of TTT is that communicative focus is lost and the shift is from student-centric to teacher-centric. Teacher delivers the lecture and students listen to it actively or passively as the case maybe.

Most importantly, as discussed earlier, the objective of a language class is not 'learning' the language but the ability to 'use' the language. With increased TTT, students get fewer opportunities to interact compromising on the core objective of learning a language.

Now, when TTT has so many disadvantages why do many teachers indulge in that? Mostly, because it is a common belief that if a teacher is not speaking then nothing is happening in the class. Teachers, since ages, are expected to take the center-stage and deliver lectures which all students should listen to attentively. Sometimes, teachers resort to talking because they are underprepared and /or unorganized. With meticulously planned lessons for each session, teachers know exactly what to do in the classroom and unnecessary talking can be avoided.

Many times teachers have a habit of echoing students' responses and repeating the instructions for eg.

Echoing

S: I think this word acts as a verb in this sentence.

T: verb...you think this is a verb...It's right. Very good! Students, please note that this word is a verb.

Repetition

T: Students, please look here. OK...now what you are supposed to do is that read this story 
Impact Factor: 4.845(SJIF) Research Journal Of English (RJOE) Vol-5, Issue-2, 2020

www.rjoe.org.in An International Peer-Reviewed English Journal

ISSN: 2456-2696

Indexed in: International Citation Indexing (ICI), International Scientific Indexing (ISI), Directory of Research Journal Indexing (DRJI) Google Scholar \& Cosmos.

carefully and try to attempt the exercises of Fill in the blanks given at the end.

Better version: Read the story and fill in the given blanks. (Signposting)

This generally happens when the teacher is unaware of her own style and unintentionally increases the TTT. Some teachers are of the view that a lot of talking results in building rapport with students. In order to sound polite, they use unnecessary words while giving instructions that further confuse students who are already struggling with the target language. In some cases, teachers tend to think aloud; again without being aware of their language.

Another situation where TTT is increased is when teachers start demonstration of their knowledge. Teacher is unarguably the most knowledgeable person in the class, but $\mathrm{s} / \mathrm{he}$ is not the only knowledgeable person in the class. Students do not come with a clean slate. They have their experiences, knowledge and awareness of the language. They should be given opportunity to share these with their classmates and hence peer learning should be encouraged. "...learning with and from each other is a necessary and important aspect of all courses. The role it plays varies widely and the forms it takes are very diverse, but without it students gain an impoverished education." (Boud, 2001)

It may be argued that teachers are the role models and demonstrate the language while talking in the form of giving instructions or initiating discussions. This argument is completely valid and is supported by many critics. Harmer in this context writes "Good TTT may have beneficial qualities, however. If teachers know how to talk to students, if they know how to rough-tune their language to the students level...then the students get to a chance to hear language which is certainly above their own productive level, but which can more or less understand." So this draws our attention towards the other important aspect ie quality. Therefore, not only TTT but also teacher talking quality (TTQ) has to be monitored.

\section{Suggestions}

Meticulously planned Instructions - Teachers may consider rehearsing the instructions to avoid unnecessary talk and avoid any slips during the class. Using gestures/prompts/signals - It's advisable to replace some instructions with gestures or nonverbal cues to reduce TTT. Initially students may not understand but if teachers regularly use gestures while giving oral instructions, students will gradually start associating gestures with instructions. 
Impact Factor: 4.845(SJIF) Research Journal Of English (RJOE) Vol-5, Issue-2, 2020

www.rjoe.org.in An International Peer-Reviewed English Journal

ISSN: 2456-2696

Indexed in: International Citation Indexing (ICI), International Scientific Indexing (ISI), Directory of Research Journal Indexing (DRJI) Google Scholar \& Cosmos.

\section{Learning-teaching-by-james-scrivener.pdf/pg 96}

More pair work - All activities in the class need not be teacher-led. Group work, pair work should be encouraged and teacher should try to bring a variation in the interaction pattern. Accepting Silence-The post on Brain pickings about the twentieth-century novelist, poet, playwright, and psychiatrist Paul Goodman who examined "the nine types of silence present in life" in his 1972 book Speaking and Language talks about kinds of silence.

"Not speaking and speaking are both human ways of being in the world, and there are kinds and grades of each. .........................baffled silence; the silence of peaceful accord with other persons or communion with the cosmos." Teachers generally feel uncomfortable if

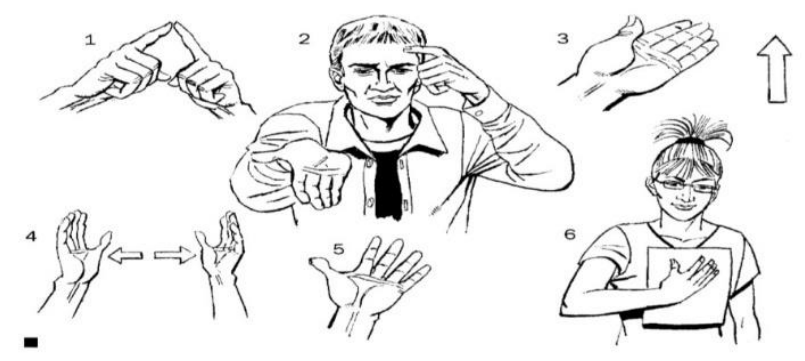
there is silence in the class. There is nothing wrong with a class being silent, if students are actively involved in some group or pair work or reading a text. Moreover, silence is important at certain stages of learning where students get some time to process the information.

Experiential learning - How do people learn things in life? Does learning happen only in the universities or within the four walls of classrooms? People generally learn by trial and error method, which is as pointed earlier in this paper, quite close to diving in the swimming pool. Students should be allowed to learn on their own and with the help of peers.

Eliciting Responses - Right from the lead-in to the error correction, focus should be on eliciting responses from the students rather than giving away the answers. Students need not be 'told' everything rather they should be learn to determine the answers with the help of guided discovery.

It is crucial to mention that as the method is a broad approach to teaching English, rather than a rigid series of activities, there are some popular misconceptions of what CLT involves. Learning a language is interactive, co-operative, learner-centered and contentbased, but the approach does not mean that learning a second language involves just 'conversation'. Though communicative focus is one of the important aspects, reading, writing and listening are equally important.

\section{Conclusion}

In the light of above discussions, it is established that though the presence of teacher is required in the classroom but the class has essentially to be student-led. It is a misunderstanding that learning can take place only through the teacher. Learning takes 
Impact Factor: 4.845(SJIF) Research Journal Of English (RJOE) Vol-5, Issue-2, 2020

www.rjoe.org.in An International Peer-Reviewed English Journal

ISSN: 2456-2696

Indexed in: International Citation Indexing (ICI), International Scientific Indexing (ISI), Directory of Research Journal Indexing (DRJI) Google Scholar \& Cosmos.

place more among the peers. Students learn more when they talk to each other in pairs and groups. Teachers need to stop teaching and start making students learn. Therefore, they need to work on reducing TTT and enhancing STT and try to achieve the deal ratio of 20:80. If the classroom looks chaotic, if the teacher is not immediately obvious, and if that teacher appears to be a learner as well as a mentor / facilitator, there is an extremely high probability that effective, deeper learning is happening!!!

\section{References:}

- Ur, P. (2012). A course in Language Teaching: Practice and Theory. Cambridge University Press, Cambridge.

- S, Jim. (2011). Learning Teaching: the essential guide to English language teaching, Macmillan Education. UK.

- K, Friederike. (1984). Keep talking: Communicative fluency activities for language teaching, Cambridge University Press, New York.

- Harmer, J. (1998). How to teach English: An introduction to the practice of English language teaching. Harlow: Longman.

- Boud, D. (2001). 'Introduction: Making the Move to Peer Learning'. In Boud, D., Cohen, Ruth \& Sampson, Jane (Ed.). Peer Learning in Higher Education: Learning From \& With Each Other. London: Kogan Page Ltd, 1-17.

- https://is.muni.cz/el/1441/jaro2009/A2MK_PPA1B/um/STT__TTT_Dagmar_Ro senbergova_Zemkova_.pdf

- Pros and cons of teacher talking time. (n.d.). Retrieved from https://www.teachingenglish.org.uk/article/pros-cons-teacher-talking-time

- Watson, A. (2017, October 2). 8 ways teachers can talk less and get kids talking more. Retrieved from https://thecornerstoneforteachers.com/8-ways-teachers-cantalk-less-get-kids-talking/

- Keyword-rank. (n.d.). Retrieved from https://www.keywordrank.com/search/communicative-language-teaching-strategies

- Administrator. (n.d.). Teacher Talk Time and Student Talk Time. Retrieved from http://www.betterlanguageteaching.com/esl-articles/57-teacher-student-talk-time 